\title{
Upwelling by Surface Gravity Waves
}

\section{Kern E. Kenyon}

4632 North Lane, Del Mar, CA, USA

Correspondence to: Kern E. Kenyon, kernken@aol.com

Keywords: Upwelling, Surface Gravity Waves

Received: April 10, $2017 \quad$ Accepted: May 24, $2017 \quad$ Published: May 27, 2017

Copyright @ 2017 by authors and Scientific Research Publishing Inc.

This work is licensed under the Creative Commons Attribution International License (CC BY 4.0).

http://creativecommons.org/licenses/by/4.0/

\section{(c) (i) Open Access}

\section{ABSTRACT}

Three upwelling mechanisms are compared that involve progressive surface gravity waves. In all cases water is pumped up from the depth of wave influence. Two of the methods that are not fully discussed in print before can occur in nature. During wind generation of surface waves in the open sea wave amplitudes and the Stokes drift increases in the direction of wave propagation implying that the Stokes drift is divergent and requiring, as a consequence, that mass be supplied to the surface from below the wave layer. The depth of wave influence of wind generated swell can reach below the light zone, so nutrients can be brought up into the sunlight and biological activity enhanced and global warming ameliorated. A third method for shallow water is the oscillation of a paddle hinged and fixed to the bottom and moved by surface waves passing by.

\section{INTRODUCTION}

Upwelling in the ocean has the potential to ameliorate global warming by bringing more nutrients up into the light zone, increasing phytoplankton growth, and decreasing $\mathrm{CO}_{2}$ concentration, first in the ocean and then in the air. Therefore, all methods of upwelling should be thoroughly studied to see what practical advantages they might have in relation to climate change.

In the present essay three methods of upwelling will be compared and contrasted. They all involve progressive surface waves and they all pump water up from the depth of wave influence. One is provided by nature and two can be man-made. Just a single mechanism is available in print at this time [1], and it has been proven to work on a small scale in a swimming pool, but no reason has been thought of for why it should not also operate well on a larger scale in the ocean.

Classical upwelling investigations have a rather long history and center around narrow strips off the west coasts of continents [2]. Such studies have more to do with equatorward cold currents and the direct effects of wind but do not involve a consideration of surface gravity waves.

\section{PIPE WAVE PUMP}

A man-made physical upwelling mechanism has been proposed [1] using rigid pipes, open at both 
ends, and drifting with the currents, held fixed vertically a little below the sea surface, with a weight at one end and flotation at the other. Wave motion across the top opening produces low pressure compared to the increased pressure of the reduced wave motion across the bottom opening, resulting in a pressure gradient that can push water upward through the pipe. These pipes could be launched into the "desert" regions of the oceans in order to produce plankton blooms and increase biological productivity in general.

\section{WIND GENERATED WAVES}

Nature has provided an upwelling mechanism of its own that is not much written about as far as I can tell (a brief mention was hesitantly put forward, but that was almost 50 years ago [3]). Surface gravity waves, in addition to energy, possess and transport linear momentum that is related to the Stokes drift and to the fact that the orbiting fluid particles advance a tiny bit in the direction of wave propagation following every orbital revolution. That in turn is due to the observed fact that all wave characteristics decrease downward from the surface including the particle velocity. These waves also possess and transport angular momentum, related to the orbital motion of the particles, but that feature is not relevant to the present discussion.

Inside a storm at sea the wave amplitudes increase with increasing horizontal distance in the direction of wave propagation, and consequently their momentum increases with that distance also. In other words, the Stokes drift becomes a divergent current, from which it is deduced that mass must be supplied to the surface from below the wave zone. A typical storm swell with a ten second period has a wavelength of about $500 \mathrm{ft}$, putting the bottom of the wave zone below the bottom of light zone (at $200-300 \mathrm{ft}$ ), where nutrients have collected from sinking and dissolving plankton.

Field studies of wave generation by wind are rare, and none have occurred in the open ocean as far as I am aware. Therefore, an accurate numerical estimate of the upwelling magnitude due to wave growth at sea by the divergent Stokes drift method does not appear to be possible at this time.

Probably the most thorough field study of wave generation starting at a coast by an off-shore wind was carried out in the North Sea [4]. The two variables of the linear momentum, wave energy and frequency, were measured as a function of offshore distance. These variable could be used to estimate the upwelling velocity with the aid of a few assumptions, since the Stokes drift equals the wave energy divided by the phase velocity [5], and the phase velocity of deep water waves is inversely proportional to the frequency. That is a job for the future. Because of the small expected magnitude, direct measurements of the upwelling velocity in the environment may not be feasible. Dye techniques could usefully be employed in the laboratory.

\section{FISH TAIL PUMP}

A third method of upwelling by progressive surface waves in relatively shallow water is proposed that probably already exists in nature but could be made more efficient through use of artificial materials. First, understanding how a fish tail operates to move a fish forward can be explained as follows. Consider a fluid particle next to a fish tail that is wagging back and forth. If the particle were stuck to the tail, its path would be along the arc of a circle, in which case it would experience a centrifugal force trying to move it more toward the rear of the tail. Since the fluid particle is not stuck to the tail, it will move to the back of the tail. By action equals reaction, Newton's third law, the fish gets a small boost forward out of each fluid particle ejected backward.

Now imagine a fish with its head pointing vertically down and bumped up against the ocean's bottom, wagging its tail. An upward current will result although the fish cannot move downward. By analogy, attach a paddle to a pivot fixed to the bottom and make waves that propagate past the paddle. As the paddle wags back and forth water will move vertically up. A paddle can be flexible like a fish tail or rigid. Where something similar exists in nature is in beds of sea weed with roots anchored in the sand. When surface waves enter such a region, the leaves oscillate back and forth. By using dye the vertical movement of the water might be made visible. 
Whether or not the fish tail concept could be adapted to upwelling in the deep ocean with a slightly submerged drifting apparatus is not known at this point.

\section{DISCUSSION}

Upwelling by wind generated surface gravity waves will take place whenever a storm occurs at sea, whether anybody likes it or not. Where man-made methods of upwelling would be most effective, perhaps, in order to maintain the biological productivity as high as possible, is in filling in the gaps between storms or where storms rarely or never occur, and in regions where no other known, non-wave related, upwelling features operate. For example, in the equatorial regions no upwelling by surface gravity waves would ever be expected because the Trade Winds blow more or less steadily all the time. Also in the North Pacific, for example, typically storms do occur in spring, winter and fall over the mid-to high latitudes, but in summer the North Pacific High swells up and shuts out the wind storms.

In contrast to the well-known coastal upwelling in thin strips about $100 \mathrm{~km}$ wide, upwelling generated by storms at sea can be as broad as the storm itself: $1000 \mathrm{~km}$. Perhaps plankton blooms could be detected remotely after a severe large-scale storm has come and gone.

\section{CONCLUSION}

Three ways to produce upwelling using surface gravity waves are outlined. The man-made method of drifting submerged rigid pipes, open at both ends, has been proven to work and published earlier. In nature wind generated surface waves have amplitudes that increase in the direction of wave propagation. Therefore, the Stokes drift increases in the same direction making the Stokes drift divergent. Mass must be supplied to the surface from below. Nutrients can then reach the light zone causing increased biological productivity. Global warming should be reduced. In shallow water a third upwelling method is to attach a paddle to a pivot fixed to the bottom and let surface waves move past and oscillate the paddle.

\section{REFERENCES}

1. Kenyon, K.E. (2007) Upwelling by a Wave Pump. Journal of Oceanography, 63, 327-331. https://doi.org/10.1007/s10872-007-0031-8

2. Neumann, G. and Pierson, W.J. (1966) Principles of Physical Oceanography. Prentice-Hall, Inc., Englewood Cliffs, NJ, 458.

3. Kenyon, K.E. (1970) Stokes Transport. Journal of Geophysical Research, 75, 1134. https://doi.org/10.1029/jc075i006p01133

4. Hasselmann, K., et al. (1973) Measurements of Wind-Wave Growth and Swell Decay during the Joint North Sea Wave Project. Deutsches Hydrographisches Institut, Hamburg.

5. Barnett, T.P. and Kenyon, K.E. (1975) Recent Advances in the Study of Wind Waves. Reports on Progress in Physics, 38, 667-729. https://doi.org/10.1088/0034-4885/38/6/001 
Submit or recommend next manuscript to SCIRP and we will provide best service for you:

Accepting pre-submission inquiries through Email, Facebook, LinkedIn, Twitter, etc. A wide selection of journals (inclusive of 9 subjects, more than 200 journals)

Providing 24-hour high-quality service

User-friendly online submission system

Fair and swift peer-review system

Efficient typesetting and proofreading procedure

Display of the result of downloads and visits, as well as the number of cited articles Maximum dissemination of your research work

Submit your manuscript at: http://papersubmission.scirp.org/

Or contact ns@scirp.org 